\title{
Menumbuhkan Jiwa, Perilaku dan Nilai Kewirausahaan Dalam Meningkatkan Kemandirian Bisnis
}

\author{
Deddy Hendarwan \\ Universitas Bina Darma \\ Email: hendarwandeddy130773@gmail.com
}

\begin{abstract}
Attitudes and behaviors are the unity of a person's character which is formed by habit everyday. Entrepreneurial behavior is influenced by internal and external factors. These factors are ownership rights (property right, PR), abilities / competencies (competency / ability,), and incentives while external factors include the environment thus Attitudes and behavior can be changed by oneself and / or there are environmental pressures / influences. there is an influence from within themselves and from outside the environment to associate then grow indi attitudes and specific behaviors. It is necessary to anticipate small businesses' difficulties by conducting an empirical study on the entrepreneurial spirit, entrepreneurial values, and assessment of entrepreneurial behavior that may affect the realization of independence efforts. This study aims to analyze the influence of entrepreneurial spirit and entrepreneurial values on entrepreneurial behavior to create business independence. The findings show that the entrepreneurial spirit has a direct positive influence on entrepreneurial behavior and positive indirect effect on the business independence.
\end{abstract}

Keywords: Attitude, behaviour, entepreneurial spirit, to create business independence

\begin{abstract}
Abstrak
Sikap dan perilaku adalah kesatuan karakter seseorang yang dibentuk oleh kebiasaan setiap hari. Perilaku kewirausahaan dipengaruhi oleh faktor internal dan eksternal. Faktor-faktor ini adalah hak kepemilikan, seperti (hak properti, PR), kemampuan / kompetensi (kompetensi / kemampuan,), dan insentif sedangkan faktor eksternal termasuk lingkungan sehingg sikap dan perilaku dapat diubah oleh diri sendiri dan / atau ada tekanan / pengaruh lingkungan. ada pengaruh dari dalam diri mereka sendiri dan dari luar lingkungan untuk mengasosiasikan kemudian menumbuhkan sikap indi dan perilaku tertentu. Hal ini diperlukan untuk mengantisipasi kesulitan bisnis kecil pada semangat kewirausahaan, nilai-nilai kewirausahaan, dan penilaian perilaku kewirausahaan yang dapat mempengaruhi realisasi upaya kemandirian. Jurnal ini menganalisis pengaruh semangat kewirausahaan dan nilai kewirausahaan pada perilaku kewirausahaan untuk menciptakan kemandirian usaha. Bahwa semangat kewirausahaan memiliki pengaruh positif langsung pada perilaku kewirausahaan dan efek tidak langsung positif pada kemandirian bisnis.
\end{abstract}

Kata kunci: Jiwa, perilaku, semangat bisnis, menciptakan bisnis yang mandiri

\section{Pendahuluan}

text

Hasil Survei Sosial Ekonomi Nasional (Susenas) yang dilakukan Badan Pusat Statistik (BPS) per September 2011 menunjukkan bahwa penduduk miskin di Indonesia sebanyak 29,89 juta orang $(13,46$ persen) dari total 222 juta penduduk.

Angka pengangguran berada pada kisaran 10,8\%- $11 \%$ dari tenaga kerja yang masuk kategori sebagai pengangguran terbuka Kewirausahaan tertuang dalam Peraturan Menteri Negara Koperasi dan Usaha Kecil dan Menengah, Nomor:6/Per/M.KUKM/VIII/2012 dengan harapan untuk mendorong dan mengakselerasi pemberdayaan Koperasi dan UMKM serta meningkatkan daya saing. 
Perilaku kewirausahaan memperlihatkan kemampuan pengusaha untuk melihat ke depan, berfikir dengan penuh perhitungan, mencari pilihan dari berbagai alternatif masalah dan pemecahannya masih kurang (Suseno 2008).

Pelaku usaha kecil sudah memiliki sikap proaktif dan inisiatif yang bagus dalam mengembangkan usaha. Pengetahuan kewirausahaan, motif berprestasi, kemandirian pribadi mempunyai daya dukung secara signifikan terhadap kemandirian usaha (Qamariyah dan Dalimunthe, 2011). Pelaku usaha kecil dalam aspek orientasi prestasi dan komitmen dengan pihak lain masih kurang baik, hal ini ditunjukkan dari tidak munculnya kemauan untuk mengembangkan produk baru serta ketergantungan pada pihak-pihak yang berkepentingan termasuk pemerintah (Suseno 2008).

Nilai-nilai kewirausahaan merupakan prasyarat yang berhubungan dengan perilaku kewirausahaan, (Frederick et al., 2006; Kickul dan Gundry, 2002; Schein, 2001). Nilai-nilai tersebut terdiri atas kreativitas, pengambilan risiko, inovasi, berorientasi prestasi, ambisi, dan kemerdekaan (Boohene et al., 2008). Nilai dalam menjalankan bisnis mengandung unsur pertimbangan yang mengembangkan gagasangagasan seorang pribadi atau sosial, maka lebih dipilih dibanding dengan bentuk perilaku atau bentuk akhir keberadaan perlawanan atau kebaikan. Nilai menjadi dasar dalam memahami sikap dan motivasi serta nilai mampu mempengaruhi persepsi perilaku dalam menjalankan bisnis, oleh karena itu nilai sangat penting untuk dipelajari dalam mengelola perilaku organisasi (Robbins, 2007).

Kewirausahaan merupakan kemampuan kreatifdaninovatif yang dijadikan dasar,dan sumber daya untuk mencari peluang menuju sukses. Proses kreatif hanya dilakukanoleh orang-orang yang memiliki kepribadian kreatif dan inovatif, yaitu orang yang memiliki jiwa, sikap, dan perilaku kewirausahaan, dengan ciri-ciri: penuh percaya diri ,indikatornya adalah penuh keyakinan, optimis, berkomitmen, disiplin, bertanggung jawab; memiliki inisiatif, indikatornya adalah penuh energi, cekatan dalam bertindak,dan aktif; memiliki motif berprestasi, indikatornya terdiri atas orientasi pada hasil dan wawasan ke depan; memiliki jiwa kepemimpinan, indikatornya adalah berani tampil beda, dapat dipercaya, dan tangguh dalam bertindak; berani mengambil risiko dengan penuh perhitungan (Suryana, 2006).

Permasalahan yang dialami bangsa Indonesia saat ini begitu kompleks, tidak hanya bidang sosial ekonomi, namun politik dan agama kian mencuat kepermukaan. Suasana yang tidak kondusif ini menyebabkan krisis ekonomi semakin berkepanjangan, sehingga mengakibatkan semakin rumitnya penyelesaian dari masalah nasional ini.

Di bidang ekonomi jumlah pengangguran dari tahun ke tahun terus meningkat, hal ini disebabkan sedikitnya lapangan pekerjaan, sedangkan jumlah lulusan sekolah menengah dan perguruan tinggi selalu bertambah. Kondisi tersebut diperparah dengan adanya PHK (Pemutusan Hubungan Kerja) dari beberapa perusahaan yang mengalami kebangkrutan.

Masalah pengangguran sebenarnya bisa diatasi apabila negara mampu menyediakan lapangan pekerjaan sebanyak mungkin. Namun hal ini sepertinya tidak mungkin bisa 
secepatnya terealisasi, karena banyaknya kendala baik dari segi ekonomi maupun sumber daya manusia itu sendiri.

Melihat kondisi ini, Purdi E. Chandra mengatakan bahwa "kita perlu adanya upaya menciptakan pengusaha baru”, sebab menjadi pengusaha itu bukan diajarkan tetapi dididik dalam pengertian non formal. Sehingga, perlu solusi bagaimana membuatpendidikan mampu menciptakan orang memiliki jiwa enterpruener. Hal itu biasa terwujud dengan model pendidikan yang bukan saja mengandalkan pada pengetahuan,tetapi juga emosional. Sementara universitas yang ada hanya menciptakan calon pencari kerja, bukan pencipta kerja.

Pemahaman kewirausahaan harus dimiliki oleh mahasiswa karena mahasiswa sebagai penerus bangsa diharapkan mampu menjadi tulang punggung negara di kemudian hari. Sehingga dengan pendidikan yang dikuasainya ia mampu menciptakan lapangan kerja, bukan menambah jumlah pengangguran setelah lulus dari sebuah perguruan tinggi.

Jadi, sebisa mungkin seorang mahasiswa dituntut untuk berpikir secara kreatif terhadap peluang bisnis yang ada di masyarakat dan berani mencoba untuk memulai usaha. Jangan bersikap apatis, karena sulit mencari pekerjaan setelah melamar ke mana-mana dan hasilnya selalu nihil. Mereka lupa bahwa sebenarnya bekerja tidak hanya di perusahaan ataupun menjadi pegawai negeri, salah satunya menjadi seorang wirausaha

\section{Literature Review}

\subsection{Hakikat dan Konsep Kewirausahaan}

Kewirausahaan pertama kali muncul pada abad 18 diawali dengan penemuan-penemuan baru seperti mesin uap, mesin pemintal, dll. Tujuan utama mereka adalah pertumbuhan dan perluasan organisasi melalui inovasi dan kreativitas. Keuntungan dan kekayaan bukan tujuan utama.

Secara sederhana arti wirausahawan (entrepreneur )adalah orang yang berjiwa berani mengambil resiko untuk membuka usaha dalam berbagai kesempatan, berjiwa berani mengambil resiko artinya bermental mandiri dan berani memulai usaha, tanpa diliputi rasa takut atau cemas, sekalipun dalam kondisi tidak pasti (Kasmir, 2007).

Beberapa definisi tentang kewirausahaan tersebut diantaranya yaitu Richard Cantillon (1775): kewirausahaan didefinisikan sebagai bekerja sendiri (self-employment). Seorang wirausahawan membeli barang saat ini pada harga tertentu dan menjualnya pada masa yang akan datang dengan harga tidak menentu.Jadi definisi ini lebih menekankan pada bagaimana seseorang menghadapi resiko atau ketidakpastian. Jean Baptista Say (1816): seorang wirausahawan adalah agen yang menyatukan berbagai alat-alat produksi dan menemukan nilai dari produksinya. Zimmerer: kewirausahaan sebagai suatu proses penerapan kreativitas dan inovasi dalam memecahkan persoalan dan menemukan peluang untuk memperbaiki kehidupan. 
Kewirausahaan merupakan kemampuan kreatif dan inovatif, jeli melihat peluang dan Selalu terbuka untuk setiap masukan dan perubahan yangpositif yang mampu membawa bisnis terus bertumbuh serta memiliki nilai.

Salah satu pendorong terciptanya inovasi selain perubahan dan keharusan untuk beradaptasi adalah kesadaran akan adanya celah antara apa yang ada dan apa yang seharunya ada,diantara apa yang diinginkan oleh masyarakat dengan apa yang sudah ditawarkan ataupun dilakukan oleh pemerintah, sektor swasta maupun Lembaga SwadayaMasyarakat (LSM). Kesimpulan yang bisa ditarik adalah bahwa kewirausahaan dipandang sebagai fungsi yang mencakup eksploitasi peluang-peluang yang muncul di pasar.Eksploitasi tersebut sebagian besar berhubungan dengan pengarahan dan atau kombinasi input yang produktif.

Seorang wirausahawan selalu diharuskan menghadapi resiko atau peluang yang muncul, serta sering dikaitkan dengan tindakan yang kreatif dan inovatif. Wirausahawan adalah orang yang merubah nilai sumber daya, tenaga kerja, bahan dan faktor produksi lainnya menjadi lebih besar daripada sebelumnya dan juga orang yang melakukan perubahan, inovasi dan cara-cara baru. Istilah wirausaha muncul kemudian setelah dan sebagai padanan wiraswasta yang sejak awal sebagian orang masih kurang sesuai dengan kata swasta. Persepsi tentang wirausaha sama dengan wiraswasta sebagai padanan entrepreneur. Perbedaannya adalah pada penekanan pada kemandirian (swasta) pada wiraswasta dan pada usaha (bisnis) pada wirausaha. Istilah wirausaha saat ini makin banyak digunakan orang terutama karena memang penekanan pada segi bisnisnya. Walaupun demikian, mengingat tantangan yang dihadapi oleh generasi muda pada saat ini banyak pada bidang lapangan kerja, maka pendidikan wiraswasta mengarah untuk survival dan kemandirian seharusnya lebih ditonjolkan.

Sedikit perbedaan persepsi wirausaha dan wiraswasta harus dipahami, terutama oleh para Pengajar agar arah dan tujuan pendidikan yang diberikan tidak salah. Jika yang diharapkan dari pendidikan yang diberikan adalah sosok atau individu yang lebih bermental baja atau dengan kata lain lebih memiliki kecerdasan emosional (EQ) dan kecerdasarn advirsity ( $A Q$ ) yang berperan untuk menghadapi tantangan hidup dan kehidupan, maka pendidikan wiraswasta yang lebih tepat.

Sebaliknya jika arah dan tujuan pendidikan adalah untuk menghasilkan sosok individu yang lebih lihai dalam bisnis, atau agar lebih memiliki kecerdasan financial (FQ) maka yang lebih tepat adalah pendidikan wirausaha. Karena kedua aspek itu sama pentingnya, maka pendidikan yang diberikan sekarang lebih cenderung dengan menggunakan kata wirausaha. Persepsi wirausaha kini mencakup baik aspek finansial maupun personal, sosial, dan profesional (Soesarsono, 2002).

Sebaliknya jika arah dan tujuan pendidikan adalah untuk menghasilkan sosok individu yang lebih lihai dalam bisnis, atau agar lebih memiliki kecerdasan financial (FQ) maka yang lebih tepat adalah pendidikan wirausaha. Karena kedua aspek itu sama pentingnya, maka pendidikan yang diberikan sekarang lebih cenderung dengan menggunakan kata 
wirausaha. Persepsi wirausaha kini mencakup baik aspek finansial maupun personal, sosial, dan profesional (Soesarsono, 2002).

\subsection{Perilaku}

Perilaku manusia adalah suatu aktivitas manusia itu sendiri (Soekidjo,1993) Secara operasional, perilaku dapat diartikan suatu respons organisme atau seseorang terhadap rangsangan dari luar subjek tersebut. (Soekidjo,1993 ). Perilaku diartikan sebagai suatu aksi-reaksi organisme terhadap lingkungannya. Perilaku baru terjadi apabila ada sesuatu yang diperlukan untuk menimbulkan reaksi, yakni yang disebut rangsangan.

Perilaku adalah tindakan atau perilaku suatu organisme yang dapat diamati dan bahkan dapat di pelajari. (Robert Kwik, 1974, sebagaimana dikutip oleh Notoatmojo 1997) Perilaku manusia pada hakikatnya adalah proses interaksi individu dengan lingkungannya sebagai manifestasihayati bahwa dia adalah makhluk hidup. (Sri Kusmiyati dan Desminiarti, 1990) Perilaku manusia adalah aktivitas yang timbul karena adanya stimulus dan respons serta dapat diamati secara langsung maupun tidak langsung. (Sunaryo, 2004)

Perilaku adalah respon individu terhadap suatu stimulus atau suatu tindakan yang dapat diamati dan mempunyai frekuensi spesifik, durasi dan tujuan baik disadari maupun tidak. Perilaku merupakan kumpulan berbagai faktor yang saling berinteraksi. Sering tidak disadari bahwa interaksi tersebut amat kompleks sehingga kadang-kadang kita tidak sempat memikirkan penyebab seseorang menerap-kan perilaku tertentu. Karena itu amat penting untuk dapat menelaah alasan dibalik perilaku individu, sebelum ia mampu mengubah perilaku tersebut.

Penelitian Rogers (1974) mengungkapkan bahwa sebelum orang mengadopsi perilaku baru (berperilaku baru), didalam diri orang tersebut terjadi proses yang berurutan, yaitu :

1. Awareness (kesadaran), yakni orang tersebut menyadari dalam arti mengetahui setimulus (objek) terlebih dahulu.

2. Interest, yakni orang mulai tertarik kepada stimulus.

3. Evaluation (menimbang - nimbang baik dan tidaknya stimulus bagi dirinya).Hal ini berarti sikap responden sudah lebih baik lagi.

4. Trial, orang telah mulai mencoba perilaku baru.

5. Adoption, subjek telah berperilaku baru sesuai dengan pengetahuan, kesadaran, dan sikapnya terhadap stimulus.

Apabila penerimaan perilaku baru atau adopsi perilaku melalui proses seperti ini didasari oleh pengetanhuan, kesadaran, dan sikap yang positif maka perilaku tersebut akan menjadi kebiasaan atau bersifat langgeng (long lasting). Notoatmodjo, 2003 hal 122.

Rasulullah, SAW adalah seorang syariah marketer yang sukses dikarenakan kejujuran dan keadilan dalam mengadakan aktivitas bisnisnya. Rasulullah sangat menganjurkan umatnya untuk berdagang dan berbisnis karena akan menimbulkan sikap mental dan kesejahteraan bagi diri dan keluarga tanpa tergantung ataupun menjadi beban orang lain: "Berdaganglah kamu, sebab dari sepuluh bagian penghidupan, sembilan diantaranya dihasilkan dari berdagang", dan juga dalam Surah An- Naba' ayat 11 : "Dan kami menjadikan siang untuk mencari penghidupan”. (QS. An- Naba': 11). 
Al-Qur'an sendiri memberikan motivasi untuk berbisnis sebagaimana tercantum dalam surah Al Baqarah ayat 2 dan 275 dan Surah Al Jumu' ah ayat 10 : "Tidak ada dosa bagimu untuk mencari karunia (rezeki hasil perniagaan) dari Tuhan mu“. (QS. Al Baqarah : 2) "Allah menghalalkan jual beli dan mengharamkan riba" (QS. al Baqarah : 275) "Apabila telah ditunaikan sembahyang, maka bertebaranlah kamu di muka bumi; dan carilah karunia Allah dan ingatlah Allah sebanyak - banyaknya supaya kamu beruntung" (QS. Al Jumu'ah : 10).

Dalam konteks bisnis, seorang entrepreneur membuka usaha baru (new ventures) yang menyebabkan munculnya produk baru atau ide tentang penyelenggaraan jasa-jasa. Karakteristik entrepreneur (Schermerhorn, 1999) yaitu (1) Fokus Pengendalian Internal; (2) Tingkat energi tinggi; (3) Kebutuhan tinggi akan prestasi; (4) Tolerans iterhadap ambiguitas; (5) Kepercayaan Diri; (6) Berorientasi pada action.

Adapun karakteristik seorang wirausahawan menurut Masykur W. adalah: (1) Keinginan untuk berprestasi; (2) Keinginan untuk bertanggung jawab; (3) Preferensi kepada resikomenengah; (4) Persepsi kepada kemungkian berhasil; (5) Rangsangan untuk umpan balik; (6) Aktivitas energik; (7) Orientasi ke masa depan; (8) Ketrampilan pengorganisasian; (9) Sikap terhadap uang.

Secara umum tahap-tahap melakukan wirausaha adalah sebagai berikut (1) Tahap memulai, tahap di mana seseorang yang berniat untuk melakukan usaha mempersiapkan segala sesuatu yang diperlukan, diawali dengan melihat peluang usaha baru yang mungkin apakah membuka usaha baru, melakukan akuisisi, atau melakukan franchising. Juga memilih jenis usaha yang akan dilakukan apakah dibidang pertanian, industri, manufaktur, produksi atau jasa. (2) Tahap melaksanakan usaha atau diringkas dengan tahap "jalan", tahap ini seorang wirausahawan mengelola berbagai aspek yang terkait dengan usahanya, mencakup aspek-aspek: pembiayaan, SDM, kepemilikan, organisasi, kepemimpinan yang meliputi bagaimana mengambil resiko dan mengambil keputusan, pemasaran,dan melakukan evaluasi. (3) Mempertahankan usaha, tahap di mana wirausahawan berdasarkan hasil yang telah dicapai melakukan analisis perkembangan yang dicapai untuk ditindak lanjuti sesuai dengan kondisi yang dihadapi. (4) Mengembangkan usaha, tahap di mana jika hasil yang diperoleh tergolong positif atau mengalami perkembangan atau dapat bertahan maka perluasan usaha menjadi salah satu pilihan yang mungkin diambil.

Secara ringkas, model proses kewirausahaan mencakup tahap-tahap sebagai berikut (Alma,2007): (1) Proses Inovasi; (2) Proses Pemicu; (3) Proses Pelaksanaan; (4) Proses Pertumbuhan.

\section{Metodologi Penelitian}

Variabel penelitian ini terdiri dari jiwa kewirausahaan, nilai kewirausahaan, perilaku kewirausahaan dan kemandirian usaha. Adapun indikator jiwa kewirausahaan adalah percaya diri, optimisme, disiplin, komitmen, berinisiatif, motivasi, memiliki jiwa kepemimpinan, suka tantangan, memiliki tanggung jawab dan human relationship. Adapun indikator nilai kewirausahaan adalah kreativitas, pengambilan risiko, inovasi, 
berorientasi prestasi, ambisi dan kemerdekaan. Adapun indikator perilaku kewirausahaan adalah pencarian usaha baru, pembaharuan strategik, ketepatan kerja dan transparansi. Adapun indikator kemandirian usaha adalah mampu memenuhi sendiri, tidak mudah menyerah, berani mengambil keputusan, berani bersaing dan menerima keunggulan pesaing. Penelitian ini menggunakan kuesioner dan wawancara mendalam dengan sasaran mengkaji indikator-indikator penelitian.

\section{Hasil dan Pembahasan}

Jiwa kewirausahaan merupakan kepercayaan dan penerimaan yang kuat terhadap perilaku kewirausahaan, kemauan untuk bekerja keras, dan memelihara hubungan antar anggota, yang berarti ada keinginan yang kuat dari anggota untuk tetap berada dalam ikatan psikologis terhadap perusahaan. Kemampuan dalam menciptakan jiwa kewirausahaan akan meningkatkan perilaku kewirausahaan menjadi semakin tinggi. Jiwa kewirausahaan mempunyai pengaruh yang positif dan signifikan terhadap perilaku kewirausahaan (Silalahi, 2007).

Organisasi yang mempunyai pengetahuan kewirausahaan akan berkomitmen terhadap perilaku kewirausahaan untuk mendapatkan kemandirian dalam mengelola usaha kecil.

Jiwa kewirausahaan mampu meningkatkan terwujudnya perilaku kewirausahaan bagi pelaku usaha kecil. Hubungan Nilai Kewirausahaan dengan Perilaku Kewirausahaan. Nilai-nilai kewirausahaan terdiri atas kreativitas, pengambilan risiko, inovasi, berorientasi prestasi, ambisi, dan kemerdekaan mampu menciptakan perilaku kewirausahaan yang kuat (Boohene et al., 2008). Kreativitas perusahaan akan mempengaruhi perilaku usaha kecil dalam menciptgakan inovasi untuk menuju kenerhasilan usaha yang lebih baik. Dengan argumentasi dan hasil riset terdahulu, maka hipotesis dua dinyatakan sebagai berikut:

Nilai kewirausahaan mampu meningkatkan terwujudnya perilaku kewirausahaan bagi pelaku usaha kecil. Hubungan Jiwa Kewirausahaan dengan Kemandirian Usaha. Kehidupan dalam berwirausaha pada prinsipnya merupakan sikap dan perilaku kewirausahaan dengan ditunjukkan melalui karakter, dan watak seseorang yang memiliki kemauan dalam mewujudkan gagasan inovatif kedalam dunia nyata secara kreatif (Hartanti 2008). Karakter merupakan suatu kepribadian yang mampu memberikan pengaruh positif dan signifikan terhadap kemandirian usaha bagi pelaku usaha kecil (Astuti dan Sukardi 2013). Jiwa kewirausahaan yang tinggi diperlukan dalam menciptakan kemandirian usaha bagi pelaku usaha kecil. Berdasarkan argumentasi dan hasil riset terdahulu, maka disajikan hipotesis tiga sebagai berikut.

Jiwa kewirausahaan mampu meningkatkan terwujudnya kemandirian usaha bagi pelaku usaha kecil. Hubungan antara Nilai Kewirausahaan dengan Kemandirian Usaha Nilai suatu kegiatan bisnis mengandung unsur pertimbangan yang memperluas gagasangagasan seorang, sehingga merupakan bentuk perilaku dalam menjalankan perusahaan menuju kemandirian usaha. Dasar dalam memahami sikap dan motivasi nilai kewirausahaan mampu mempengaruhi perilaku dalam menjalankan bisnis, sehingga nilai merupakan tingkah laku yang sangat penting dalam mengelola kemandirian perusahaan (Robbins 2007). 
Nilai kewirausahaan mempunyai pengaruh positif dan signifikan terhadap kemandirian usaha, oleh sebab itu peningkatan nilai yang tinggi terhadap pelaku usaha kecil mampu meningkatkan tumbuhnya kemandirian usaha (Djodjobo dan Tawas 2016). Nilai kewirausahaan mampu meningkatkan terwujudnya kemandirian usaha bagi pelaku usaha kecil. Hubungan Perilaku Kewirausahaan dengan Kemandirian Usaha Kebijakan strategis dalam mengembangkan sektor usaha kecil untuk menjadikan usaha kecil yang mandiri, dibutuhkan kemampuan dalam meningkatkan penguatan perilaku usaha dalam berbagai sektort.

Perilaku kewirausahaan mampu meningkatkan terwujudnya kemandirian usaha bagi pelaku usaha kecil. Jiwa kewirausahaan akan mengalami peningkatan secara signifikan terhadap kemandirian usaha secara tidak langsung dengan dimoderasi oleh perilaku kewirausahaan, hasil ini sesuai dengan penelitian yang dilakukan Amelia (2009).

\section{Simpulan}

Dari uraian di atas dapat disimpulkan bahwa,secara empiris bahwa jiwa kewirausahaan berpengaruh positif dan signifikan terhadap perilaku kewirausahaan. Kondisi ini menunjukkan bahwa jiwa kewirausahaan yangdimiliki pelaku usaha kecil mampu meningkatkan terbentuknya perilaku kewirausahaan, mendoronga serta menumbuhkan semangat bagi pelaku usaha kecil dalam menjalankan kegiatan usaha.

Dalam rangka penciptaan dan pengembangan wirausaha yang tangguh (baik wirausaha baru maupun yang berawal dari wirausaha yang sudah ada) tidak dapat dilakukan tanpa kajian dan pertimbangan yang matang, Strategi dan program yang dijalankan tanpa kajian yang matang tidak akan memberikan hasil yang optimal. Salah satu pola penciptaan wirausaha baru yang tangguh dapat dilakukan pada tataran penciptaan iklim yang mampu menanamkan budaya wirausaha, dan pada tataran operasional. Penelitian Husaini (2004) yang mengatakan bahwa jiwa kewirausahaan berpengaruh positif dan signifikan terhadap perilaku kewirausahaan.

Berarti pelaku usaha kecil diharapkan mengedepankan jiwa kewirausahaan dalam setiap kegiatan bisnis dengan sebaikbaiknya supaya dapat membentuk perilaku kewirausahaan yang kuat dan tangguh. Penelitian Basuki (2007) yang menunjukkan bahwa jiwa kewirausahaan berpengaruh positif dan signifikan terhadap kemandirianusaha. Apabila jiwa kewirausahaan semakin meningkat maka kemandirian usaha pelaku usaha kecil juga akan semakin kuat dan tangguh dalam menjalankan bisnis. Namun demikian walaupun jiwa kewirausahaan meningkat, tidak selalu akan menyebabkan terbentuknya kemandirian usaha bagi pelaku usaha kecil. Sehingga terbentuknya kemandirian usaha tidak tergantung pada baik atau buruknya jiwa kewirausahaan bagi pelaku usaha kecil. Hasil kajian ini sesuai dengan penelitian Haryono dan Khoiriyah (2012) yang menyatakan bahwa perilaku kewirausahaan berpenaruh positif dan signifikan terhadap terbentuknya kemandirian usaha.

Jiwa kewirausahaan akan mengalami peningkatan secara signifikan terhadap kemandirian usaha secara tidak langsung dengan dimoderasi oleh perilaku kewirausahaan, hasil ini sesuai dengan penelitian yang dilakukan Amelia (2009). 
pemberdayaan usaha kecil yang ada menunjukkan bahwa persolaan kemandirian usaha masih merupakan beban bagi pelaku usaha kecil. Pemberdayaan usaha kecil dengan mengelola jiwa kewirausahaan diharapkan dapat menciptakan pelaku usaha kecil yang mandiri, serta tangguh dalam menghadapi persaingan terutama dari produk-produk global yang saat ini membanjiri pasar domistik. Adanya perubahan pengelolaan nilai kewirausahaan bagi pelaku usaha kecil yang masih menggunakan polakekeluargaan, supaya lebih dikembangkan modelkoperasi dengan harapan akan lebih efisien, efektif serta mengurangi kebiasaankebiasaan yang tidak mendukung terbentuknya kemandirian usaha.

Keterlibatan pemerintah daerah dilibatkan terutama dalam memberdayakan keahlian pelaku usaha kecil melalui pelatihan untuk produk-produk yang memerlukan ketrampilan khusus seperti desain batik, pengolahan hasil perkebunan, kerajinan sehingga akan menghasilkan produk yang berkualitas. Kemandirian usaha kecil memerlukan perlindungan pengelolaan usaha agar dapat dengan mudah untuk menjalankan bisnis, oleh karena itu dibutuhkan peran serta pemerintah daerah, perguruan tinggi dan stakeholders untuk mewujudkan adanya peraturan daerah tentang pengelolaan usaha kecil yang dapat melindungi pelaku usaha kecil. Sehingga dapat meningkatkan produktifitas serta berdampak pada pertumbuhan usaha yang sinergis dalam menjamin kelangsungan hidup perusahaan.

\section{Daftar Pustaka}

Alma, B. (2001). Kewirausahaan. Bandung: Alfa Beta.

Amelia. (2009). Pengaruh pengetahuan kewirausahaan dan kemandirian pribadi terhadap kinerja usaha (studi kasus pada pedagang pakaian pajak sore jalan jamin ginting). Tesis: FE Universitas Sumatera Utara.

Astuti, S., \& Sukardi, T. (2013). Faktor-faktor yang mempengaruhi kemandirian untuk berwirausaha pada siswa SMK. Jurnal Pendidikan Vokasi, 3(3), pp. 334-346.

Bass, B. M., \& Avolio, B.J. (1993). Tansformational leadership and organizational culture. Public Administration Quarterly, 17(1), pp. 112-121.

Basuki, R. (2007). Analisis hubungan antara motivasi, pengetahuan kewirausahaan, dan kemandirian usaha terhadap kinerja pengusaha pada kawasan industri kecil didaerah pulogadung. Jurnal Usahawan, 2(10), pp. 1-8.

Boohene, R., A. Sheiridan, \& Kotey, B. (2008). Gender, personal values, strategiesand small business performance: A Ghanaian case study.

Dalimunthe, J. (2012). Pengaruh pengetahuan kewirausahaan, motif berprestasi, dan kemandirian pribadi terhadap daya saing usaha (pengusaha kuliner skala kecil di jalan Dr. Mansur Medan). Jurnal Ekonomi,14(1), pp. 20-25.

Frederick, H. H., Kuratko, D.F.., \& Hodgestts, R.M. (2006). Entrepreneurship: Theory, process and practice. Asia-Pacific Edition, Cengage Learning

Glendoh, S. H. (2013). Pembinaan dan pengembangan usaha kecil. Jurnal Manajemen dan Kewirausahaan, 3(1), pp. $1-13$.

Husaini. (2004). Pengembangan jiwa kewirausahaan melalui peningkatan pendidikan kejuruan di Kabupaten Indragiri Hilir. Tesis. Sekolah Pascasarjana IPB Bogor.

Karsidi, R. (2007). Pemberdayaan masyarakat untuk usaha kecil dan mikro (pengalaman empiris di wilayah Surakarta Jawa Tengah). Jurnal Penyuluhan, 3(2), pp. 136-145. 
Peraturan Menteri KUKM N0: 02/Per /M.KUKM///2008. Tentang Pemberdayaan Business Development Services-Provider (BDS-P) untuk Pengembangan Koperasi, Usaha Mikro, Kecil dan Menengah (KUMKM) Qamariyah, I., dan D. M. Peraturan Menteri Negara Koperasi dan Usaha Kecil dan Menengah Nomor.06/Per/M.KUKM/VIII/ 2012 tentang Pedoman Penanganan Benturan Kepentingan di Lingkungan Kementerian Koperasi Dan Usaha Kecil Dan Menengah.

Suryana. (2009). Kewirausahaan, Pedoman Praktis: Kiat dan Proses menjadi Sukses, Salemba Empat.

\section{Copyright Disclaimer}

Copyright for this article is retained by the author(s), with first publication rights granted to the journal. 